\title{
ENCAPSULATION OF PROTEASE ENZYME FOR DOMESTIC APPLICATION
}

\author{
Sawsan Abd Ellatif*, Soad A. Abdelgalil ${ }^{1}$, Rania S. Ahmed, Nadia A. Soliman \\ Department of Bioprocess Development, Genetic Engineering and Biotechnology Research \\ Institute (GEBRI), City for scientific Research and Technology Applications (SRTA City), \\ Universities and Research Institutes Zone, New Borg El-Arab, Alexandria, Egypt
}

*Corresponding author E-mail: sghany2000@yahoo.com, sabdellatif@ srtacity.sci.eg

\begin{abstract}
The use of alkaline protease as commercial catalysts has increased significantly in recent years. Often main industrial and commercial uses, like the food fabric and medical diagnostics industries depend heavily on the protease enzyme. The free movement of enzymes is constrained in the cell immobilization technique and a continuous fermentation method can be used. The procedure was usually used with different carriers, such as chitosan, agar and alginate, to create alkaline proteases. In conjunction to the encapsulation of an enzyme using an Encapsulator instrument, we attempted to use this technique to examine the implementation of individual matrices to immobilize the protease enzyme. This enzyme was previously recovered from Bacillus Pseudofirmus Mn6 EU315248. Some physical characteristics of the immobilized enzyme such as activity temperature, $\mathrm{pH}$ effect and operational stability were assessed. Results revealed that the maximum $\mathrm{pH}$ stability attained throughout the chitosan matrix-entrapped enzyme, when incubated at $\mathrm{pH}$ of 10.5 for $15 \mathrm{~min}$. is nearly $200 \%$. The protease enzyme immobilized in chitosan, displayed excellent stability when incubated at $50^{\circ} \mathrm{C}$ for $1 \mathrm{~h}$ with a local detergent. The enzyme retained its maximal activity even after $1 \mathrm{~h}$ of incubation with the majority of the tested detergents. Washing performance of the immobilized alkaline protease was also applied on two types of dirty cloth spots, i.e. blood and chocolate spots. Results confirmed that the immobilized protease enzyme must be used as one of the ingredients in the detergents industry.
\end{abstract}

Keywords: Protease, Immobilization, Encapsulator, Relative activity, Detergents

\section{INTRODUCTION}

Enzymes are effective in the industrial and pharmaceutical processes, as well as in the sector of biotechnology (Sharifi, et al., 2019). In 2010, the supplementary market demand for industrial enzymes was 3.3 billion dollars, whereas in 2015 it was 4.94 billion dollars (BBC Research Report 2011).

Proteases are one of the biggest and most complex enzyme classes recognized up till now. Such enzymes hydrolyze proteins into small peptides or free amino acids. Alkaline 
proteases are among the most prominent classes of industrial enzymes in detergents, clothing and meat sectors. They comprise 35\% revenue of the microbial enzymes (Ramnani, et al., 2005). Grebshova et al., (1999); Moreira et al., (2002) reported that the application of proteases to the detergents significantly increased the washing benefits, by eliminating protein including blood and eggs, subsequently reducing pollution. Based on their expression at various $\mathrm{pH}$ values, proteases are graded as acidified, acidic and/or alkaline (Al-Shehri, et al., 2004). Lopez, et al., (1997) defined immobilization as a term used to describe large variety of spherical perforations of the cells or particles attached andlor immobilized. It can be applied to every biocatalyst type of animal or plant cells, including enzymes and cell organs. The study of Peinado, et al., (2006) pointed that, the different types of immobilization technologies have widespread use in pharmaceutical, agricultural, food, biotechnological sectors, as well as in biosensor industries. Currently, the majority of cleaning products is based on similar structures, and involves the use of similar ingredients. Previous study of Susumu, et al., (1998) reported that the formulation of detergents of high consistency usually contain one or more enzymes, in order to improve their effectiveness.

Recent study of Sharifi, et al., (2019) demonstrated that enzyme immobilizations have more advantages over free enzymes, as the simplicity of products separation facilitates the implementation of the enzymes and supports an efficient response technology. On the other hand, the reuse of enzymes offers cost benefits, which are often an important requirement for enzyme-catalyzed processes. According to Melo et al., (2017), the characteristics of immobilized enzymes are based upon the features of both the enzyme and the carrier. The unique dynamic existence of the former guarantees a defined enzyme with distinguished chemical, biological, mechanical and kinetic properties.

Protease immobilization into proper support structures serves a vital role in diverse areas of the development and detergent factories. Elnashar et al., (2014) added that enzyme immobilization enables quick isolation and reuse of the enzyme from the products. Indeed, it is necessary to properly choose the immobilization methods and materials, to reduce its disadvantages. Previous study of Bommarius and Paye, (2013) revealed that enzymes are typically immobilized using the strategies of direct adsorption, ionic attachment, covalent bindings, cross-linking and entrapment. The entrapment approach was regarded as the most applicable among these reported methods, which involves the entrapment of an enzyme within a semi-permeable membrane capsule used in aqueous solutions. The protease enzyme was obtained from Bacillus pseudofirmus Mn6 EU315248 during the study of Abdel-Fattah, et al., (2009). In this study, the efficiency of various matrices including; agar, sodium alginate and chitosan, for immobilization of the alkaline protease was investigated. Moreover, the temperature, $\mathrm{pH}$, stability, reusability and fitness of the immobilized enzyme when used as a practical detergent have been also investigated, in order to provide modern basis for future application of the immobilized enzymes. 


\section{Material and Methods}

\section{Chemicals, reagents and culture media}

All reagents used in this study were of analytical grade from MERCK (Germany), Sigma (USA), and Fluka (Switzerland).

\section{Enzyme production and preparation}

The purified alkaline protease (kept in lypholized form) was obtained from Bacillus pseudofirmus Mn6 during the study of Abdel-Fattah, et al., (2009).

\section{Enzyme immobilization using different matrices}

\section{Immobilization using Calcium alginate}

About $0.9 \mathrm{~g}$ sodium alginate was suspended in $30 \mathrm{ml}$ of boiling water to form a solution concentration of $3 \%$, autoclaved at $121^{\circ} \mathrm{C}$ for $15 \mathrm{~min}$. The suspension was stirred for 10 min. using a glass rod, allowed to cool to ambient temperature. This was held in a sterile syringe, and released drop wise into a cool $0.2 \mathrm{M} \mathrm{CaCl}_{2}$ solution with continuous agitation. Spherical beads were formed and kept at $4^{\circ} \mathrm{C}$ for $1 \mathrm{~h}$. All processes were aseptically carried out under a laminar flow cabinet according to Johnsen, et al., (1986). We monitor for the impact of varying temperatures ranging from $40^{\circ} \mathrm{C}$ to $80^{\circ} \mathrm{C}$ on the immobilized protease enzyme and correlate it with free enzymes under different $\mathrm{pHs}$ values $(9,9.5,10,10.5$ and 11$)$.

\section{Agar immobilization (Ram, et al., 2012).}

The molten agar $(2 \%)$, which has been held at $40{ }^{\circ} \mathrm{C}$ poured in flat Petri-plates, with a particular quantity of the enzyme suspension (equated to $0.03 \mathrm{~g}$ of lyophilized formulation weight). Let the agar to solidifying then cut into discs. Sterile 0.1 M phosphate buffer ( $\mathrm{pH}$ 7.0) was added and kept at $4{ }^{\circ} \mathrm{C}$ for 1 hour. After curing, the phosphate buffer was rinsed and cleaned with distilled water 3-4 times and kept in the fridge. The impact of various temperatures of about $40{ }^{\circ} \mathrm{C}$ to $80^{\circ} \mathrm{C}$ is measured and also under different $\mathrm{pH}$ values $(9,9.5,10,10.5$ and 11$)$ tested on immobilized protease enzyme and compared with free enzyme.

\section{Chitosan immobilization (Rezakhani, et al., 2014).}

\section{Preparation of solutions}

$500 \mathrm{~mL}(5 \%)$ Chitosan solution with $100 \mathrm{~mL} 1 \mathrm{M} \mathrm{NaOH}$ was developed. A hygienic syringe was inserted to the previous chitosan solution and drop-wise into the $\mathrm{NaOH}$ solution, a magnetic agitator was applied to the solution. It produced beads of nearly 
$3 \mathrm{~mm}$ width. The beads have been washed many times with sterile water to get rid of the excess $\mathrm{NaOH}$.

After that, alkaline protease activity tested for the immobilized constructs under $\mathrm{pH}$ values varies from 9 to 11 (at $55^{\circ} \mathrm{C}$ ) with a $50 \mathrm{~mm}$ buffer of $\mathrm{Na}$ Phosphate and measured also under temperatures between $40{ }^{\circ} \mathrm{C}$ and $90{ }^{\circ} \mathrm{C}(\mathrm{pH} 10.5)$ was carried out to examine the impact of $\mathrm{pH}$ and temperature on the immobilized preparation of alkaline protease production.

\section{Enzyme Formulation}

\section{Encapsulation of protease enzyme in chitosan beads using InotechEncapsulator}

In an attempt to produce protease enzyme-chitosan beads as a pre-industrial step, enzyme-chitosan solution was sprayed in $\mathrm{NaOH}$ solution $(1 \mathrm{M})$ using Inotech Encapsulator IER-50 (Switzerland). At $550 \mathrm{~Hz}$ and $1.40 \mathrm{kV}$, the process was calibrated. In order to evaluate the effectiveness of the technique, the beads were monitored for proteolytic activity and for loading capacity of the beads. Loading capacity (\%) was calculated from the following equation:

Loading capacity $(\%)=\mathrm{A} 1 / \mathrm{A} 0 \times 100$

Where, $\mathrm{A} 0=$ total activity of added enzyme

A1 = total activity of actual entrapped enzyme

\section{Detergent application}

The protease $(0.5 \mathrm{U} / \mathrm{ml})$ at a concentration of $7 \mathrm{mg} / \mathrm{ml}$ was incubated over $1 \mathrm{~h}$ with different natural detergents, such as Master, Persil, Ariel, Oxi and a commercial detergent. Adequate aliquots have been discarded at various times duration, and standard test protocols have assessed the residual enzyme activities. It was contrasted with the controls that incubated without any detergent in identical conditions. In addition, all detergent solutions used were assayed for alkaline protease activity without incubating the enzyme to eliminate the possibility of protease (if present) embedded as a detergent component.

\section{Distaining of blood-stained and chocolate fabric}

Application of blood and chocolate stains to a white cotton fabric $\left(4 \mathrm{~cm}^{2} \times 4\right.$ $\mathrm{cm}^{2}$ ) using a modified method (Kumar and Bhalla, 2004) was evaluating for protéase washing performance. The stained parts would dry up at $55^{\circ} \mathrm{C}$ in the microwave. They have been kept in glass bottle which contained $100 \mathrm{U} / \mathrm{mL}$ of either tested free protease enzyme or immobilized in chitosan in equal amounts, then complete with $20 \mathrm{ml}$ glycine 
buffer $\mathrm{pH} 10$ and incubated into the glass container with $60^{\circ} \mathrm{C}$ for 30 minutes. Under identical situations a control test was performed, with the exception of the addition of no enzymes. The elimination of stain was visually checked.

\section{Assay of alkaline protease enzyme activity}

Alkalin protease assessments by adding a $50 \mathrm{mM}$ Glycine $\mathrm{NaOH}$ buffer $\mathrm{pH} 10$, to 1 $\%$ of bovine milk casein and incubated with $0.5 \% \mathrm{NaCl}$ at $60^{\circ} \mathrm{C}$, according to the quantitative measure of (Anson, 1938). The enzyme amount, which yielded $1 \mu \mathrm{mol}$ of tyrosine per minute in the assessment conditions, was denoted as one unit of enzyme activity.

\section{Reusability of immobilized enzyme}

In order to minimize the expense of the enzyme, the reusability of the immobilized enzyme is very significant. When keeping in mind its fit for various applications, this is an important factor. The beads were re-used with the glycine- $\mathrm{NaOH}$ buffers $(0.1 \mathrm{~m}, \mathrm{pH} 10)$ and placed in the new reaction mixture around 10 minutes at $60^{\circ} \mathrm{C}$ to assess the re-usability of the immobilized chitosan matrix enzyme and then were checked with proteolytic action.

\section{Results}

As mentioned in material and methods different matrices were used for immobilization of the alkaline protease, then the effect of both temperature and $\mathrm{pH}$ values were illustrated in each case compared to free enzyme.

The ability of specific matrices with alkaline protease entrapment methods in this research was investigated. The matrices used were agar, calcium alginate and chitosan (Figure1 b, c and d), respectively. Each form was prepared as described in material and method section. 
(a)

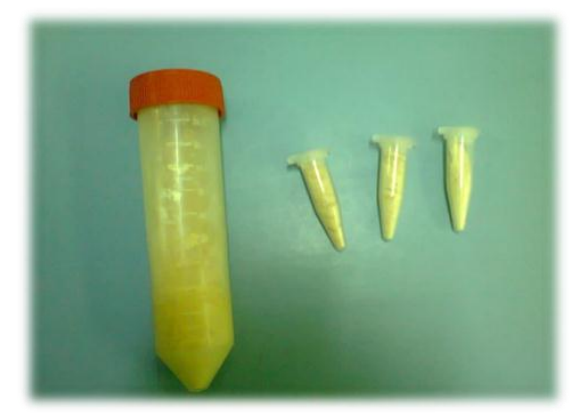

(c)

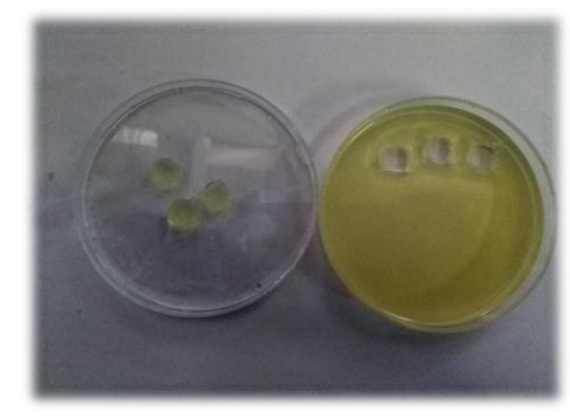

(b)

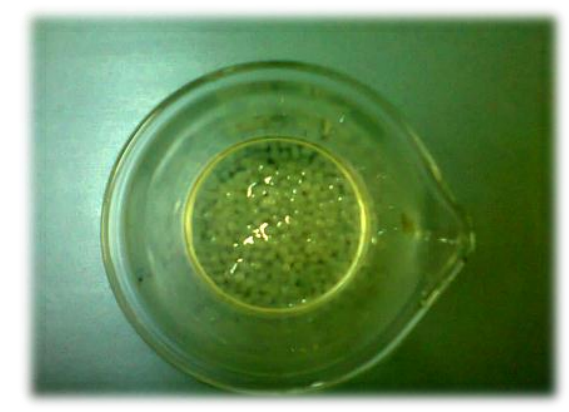

(d)

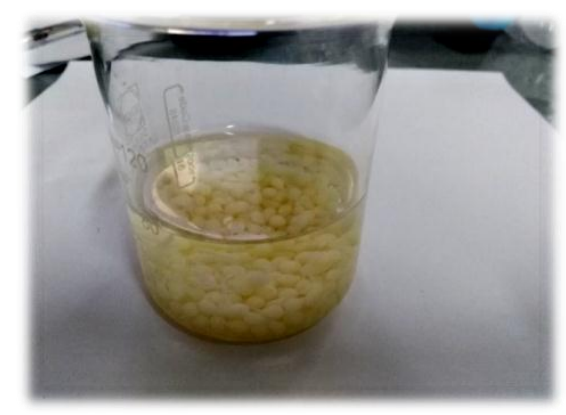

Figure 1.(a) Free lyophilized enzyme, (b) Immobilized protease in Ca-alginate, (c) Immobilized protease in agar, (d) Immobilized protease in chitosan.

Incubating the enzyme at $1 \mathrm{~h}$ at $\mathrm{pH} 10.5$ and specific temperatures $(50,55$ and 60 ${ }^{\circ} \mathrm{C}$ ) (Figure 2). Thermal stability of the enzyme has been tested. The thermal stability pattern of protease was shown that the immobilized enzyme beads (casein 1\%) is incubated with the substrate at variables in temperature of 40 to $90^{\circ} \mathrm{C}$ to study the effect of the temperature on the operation of the investigated alkaline protease enzyme. Relative activity (\%) of the protease tests (Figures 2, a, b, c, and d) revealed that on all three separate matrices, the maximal thermal temperature for each free and immobilized enzyme was $60^{\circ} \mathrm{C}$. The proportion of the relative activity was estimated as the average of percentage of activity of the enzyme after incubation to its initial activity. In addition, the enzyme retained about $60 \%$ of its activity at $90^{\circ} \mathrm{C}$ in case of using chitosan as a matrix. However, it was greatly deactivated at the same temperature in case of the free enzyme and also, alginate and agar often used as immobilization matrices. 

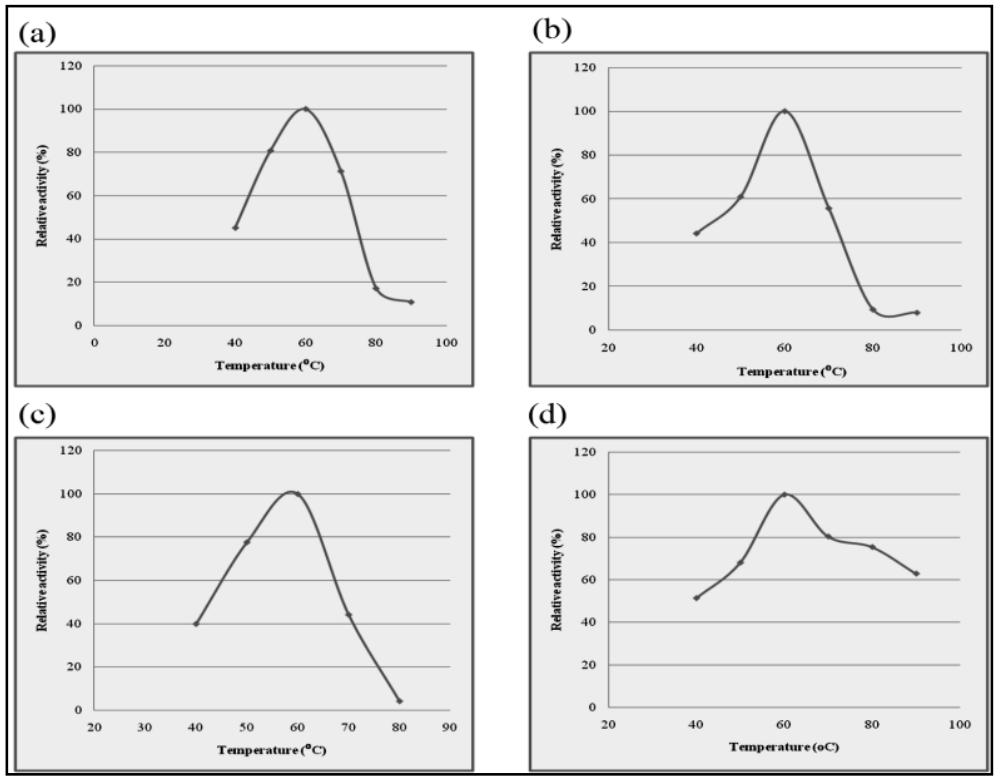

Figure 2.Effect of temperature on Bacillus pseudofirmusM6 alkaline protease enzyme activity; (a)free enzyme, (b) immobilized protease in Ca-alginate, (c) immobilized protease in agar, (d)immobilized protease in chitosan.

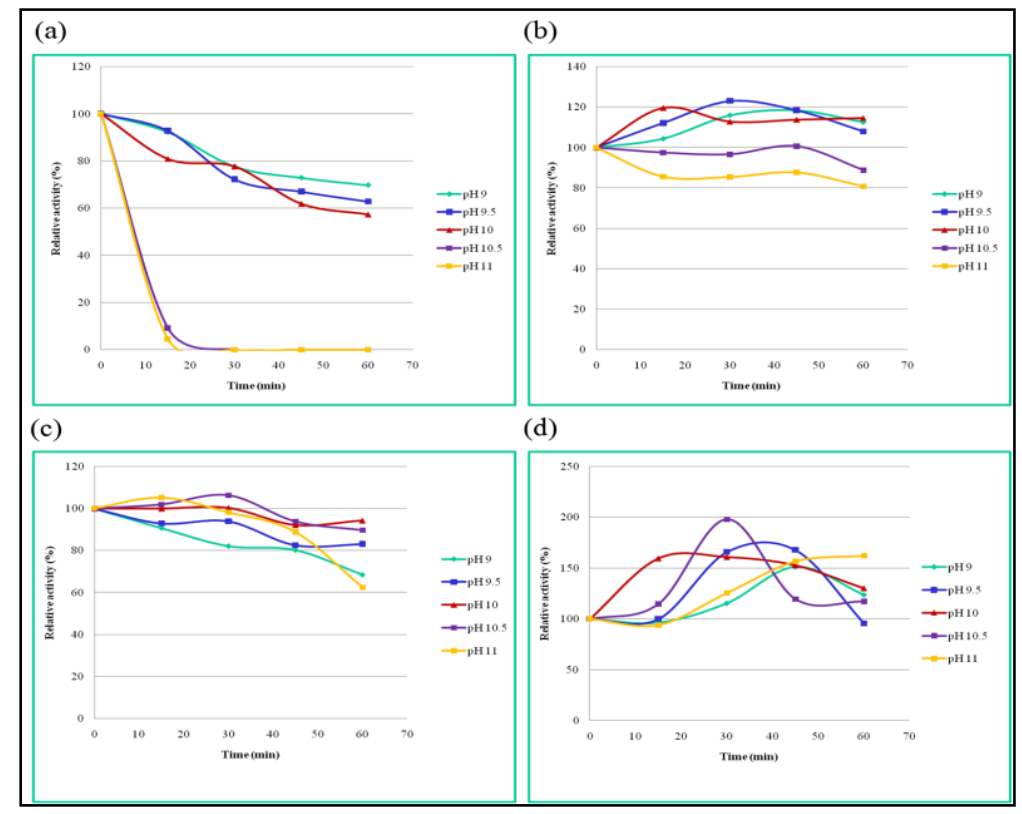

Figure 3.Effect of $\mathrm{pH}$ on Bacillus pseudofirmusM6 alkaline protease enzyme stability; (a) free enzyme, (b) immobilized protease in Ca-alginate, (c) immobilized protease, (d) immobilized protease in chitosan. 
Results showed that the chitosan beads formulated using Inotech Encapsulator had a high loading capacity as they could trap about $92 \%$ of the protease enzyme. The beads were removed and washed after every application with the Glycine-NaOH buffer $(0.1 \mathrm{M}, \mathrm{pH} 10)$ to create reusability of the immobilized enzyme in the chinosan matrix and included in the $10 \mathrm{~min}$ new reaction solution at $60^{\circ} \mathrm{C}$ and reassessed for proteolytic operation. The outcome showed that the chitosan-entrapped enzyme retained about $95 \%$ of its original activity after reusing for 3 cycles (Figure4), and this indication for the complete stability of chitosan as a matrix at $60 \circ \mathrm{C}$ for at least $30 \mathrm{~min}$.

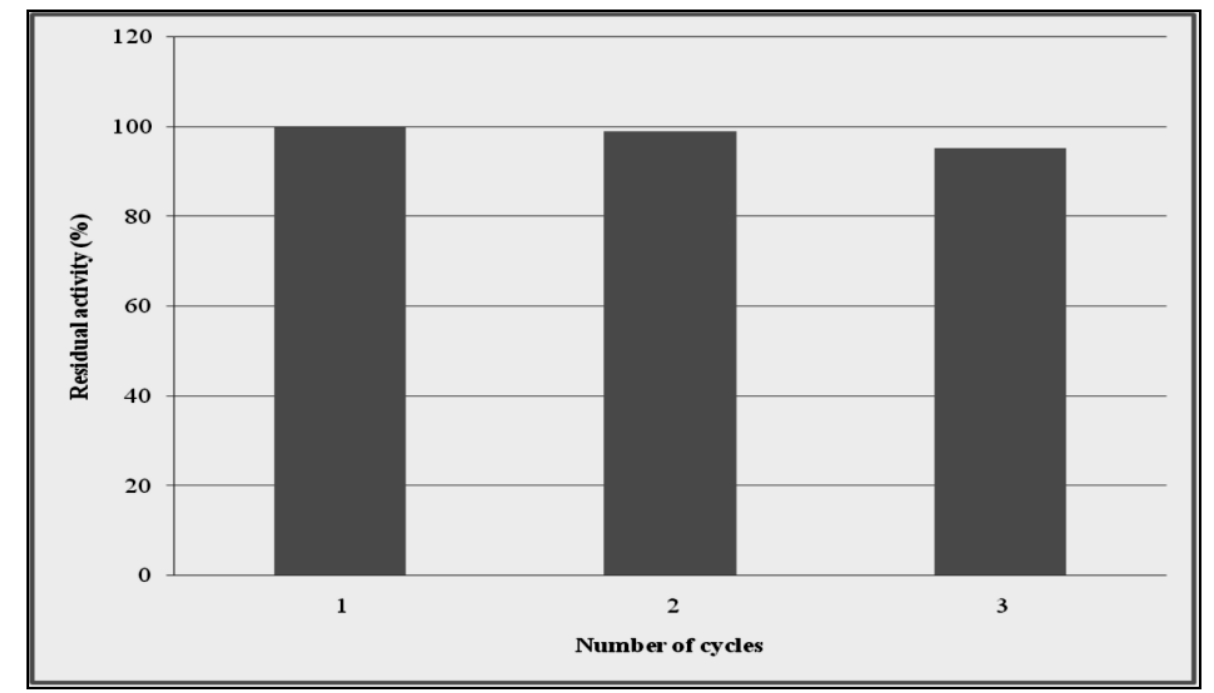

Figure 4. Reusability of the protease enzyme immobilized in chitosan beads.

To study the compatibility of the immobilized enzyme on the different matrices with detergents, Incubation of free and immobilized enzymes with different marketing detergents such as Leader, Persil, Ariel, Oxi and commercial detergent at $7 \mathrm{mg} / \mathrm{mL}$ for $1 \mathrm{~h}$ was allowed for testing the establishment of protease in economic detergents. In the past, the residual behaviors were calculated and linked to the free enzyme. This was compared to the control that was incubated without a detergent under the same conditions.

Results (Figure 5 a, b,c and d) showed that the immobilized protease in all matrices showed higher residual activities when incorporated with the commercial detergent (without Trade mark) compared with that of the free enzyme(Venugopal and Saramma,2006). In addition, protease immobilized in chitosan showed the highest relative activity (\%) reaches up to $151.8 \%$ when incorporated with Oxi detergent (Trade mark) rather than it reached to $133.8 \%$ of its relative activity when incubated with Persil detergents (Trade mark) compared with the protease enzyme immobilized in both agar and alginate that gives the lowest activities. 
(a)

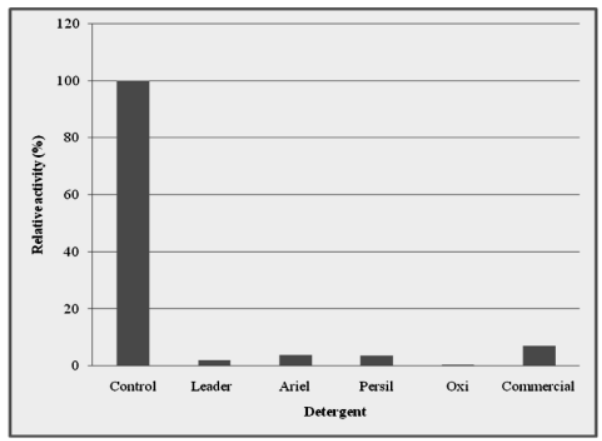

(c)

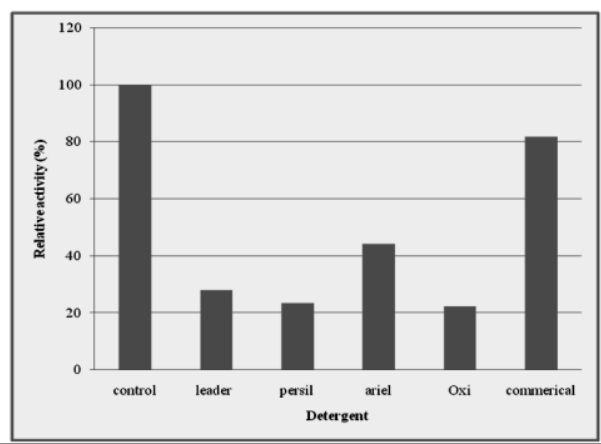

(b)

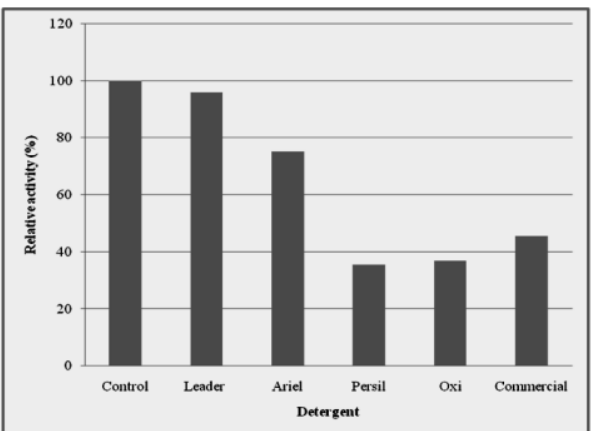

(d)

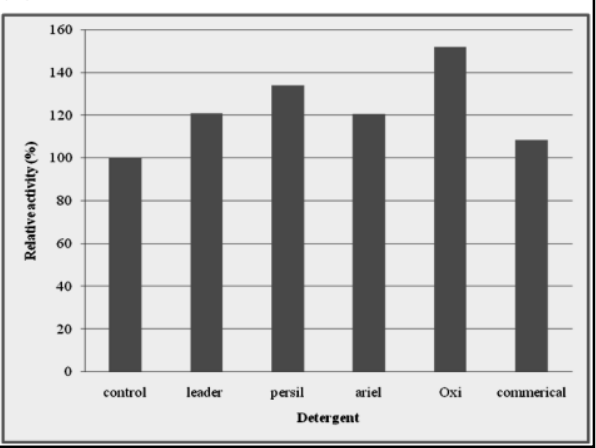

Figure 5. Effect of some commercial detergents on protease enzyme activity; (a) free enzyme, (b)immobilized protease in Ca-alginate, (c) immobilized protease in agar, (d) immobilized protease in chitosan.

Both of free and chitosan-immobilized enzyme was tested for their applicability in removal of blood and chocolate stains. To do this, blood and chocolate individually colored into white cotton cloths and oven dried for 2 hours at $55^{\circ} \mathrm{C}$. Each piece of cloth was then incubated with either the free or chitosan beads-immobilized enzyme at $60^{\circ} \mathrm{C}$. Results were compared with that of the control which contained the cloth piece incubated with only the buffer. The results (Figure 6) revealed that the immobilized enzyme had higher efficiency than the free enzyme. This is due to its high stability in high temperature and $\mathrm{pH}$ values. In addition, it could completely remove the chocolate stain after incubating with the cloth for $2 \mathrm{~h}$, while it could remove the blood stain after only $30 \mathrm{~min}$. 


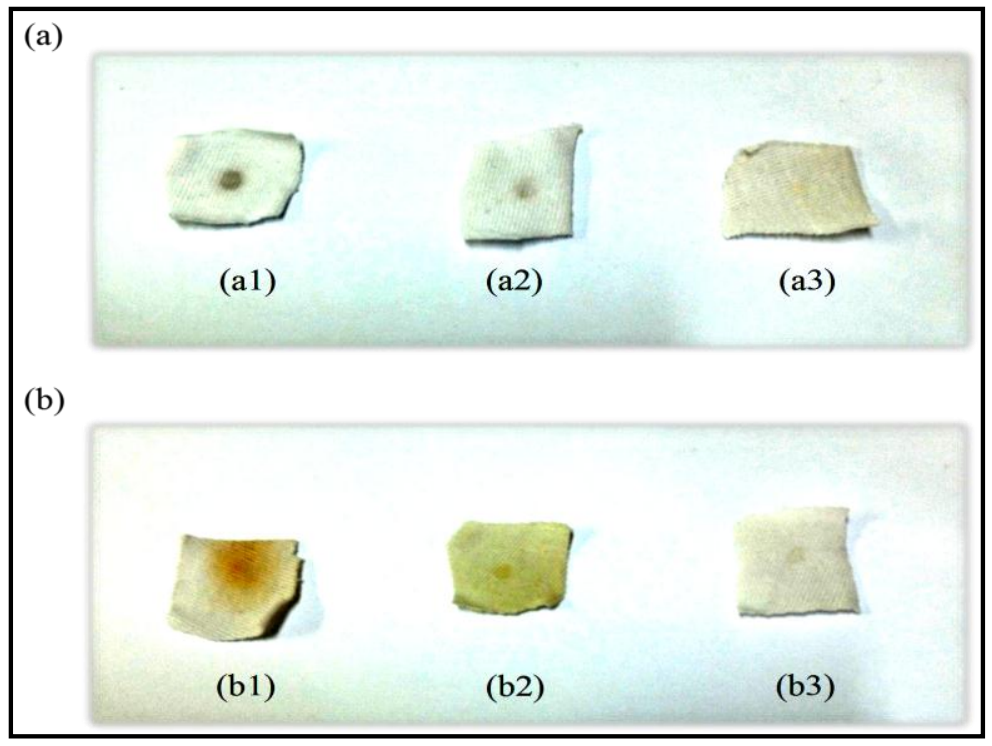

Figure 6. Application of protease in removal of stain: (a) chocolate stain; (a1) control, (a2) using free enzyme, (a3) using chitosan-immobilized enzyme, (b) blood stain; (b1) control, (b2) using free enzyme, (b3) using chitosan-immobilized enzyme.

\section{Discussion}

In particular, increase in temperatures speed the action of the enzyme, because at higher temperatures, molecules migrate much quickly, so that it will be possible that the enzyme can interact with a substrate rapidly. It was concluded that the best temperature recorded to be $50^{\circ} \mathrm{C}$ for the enzyme when captured in alginate beads (Anwar, et al., 2009). From Figure 2 the temperature of $60^{\circ} \mathrm{C}$ for immobilized enzymes has been established as being the highest and safest temperature for enzyme operation. Many researchers recorded that the optimum temperature was as high as $50{ }^{\circ} \mathrm{C}$ (Shaheen, et al., 2008; Boominadhan, et al., 2009). On the other hand the ideal temperature of protease activation has been documented at $37^{\circ} \mathrm{C}$. for Bacillus pumilus SG2 and Bacillus sp. CFR3001 proteolyticus (Sangeetha, et al., 2010; Nagalakshmi, and Ramesh,2009; Bhaskar, et al., 2007).

The detergent contained proteases should be highly active at high $\mathrm{pH}$ values in order to be effective while washing. To evaluate the $\mathrm{pH}$ stability of the free and immobilized enzyme, buffers of specific $\mathrm{pH}$ values were used. The substrate was incubated into each of the free and immobilized enzymes for $1 \mathrm{~h}$ and aliquots were taken every $15 \mathrm{~min}$ to check the residual proteolytic activity. Results revealed that the free enzyme has the least $\mathrm{pH}$ stability as it lost its whole activity after incubation for $15 \mathrm{~min}$ in either $\mathrm{pH} 10.5$ or 11 . On the other hand, use of each of the three matrices for enzyme immobilization increased $\mathrm{pH}$ stability. The enzyme showed its highest stability when immobilized on chitosan 
matrices followed by Ca-alginate and agar. Using chitosan as a matrix for enzyme immobilization caused the enzyme activity to be raised to about $200 \%$ of its original activity when incubated at $\mathrm{pH} 10.5$ for $30 \mathrm{~min}$. In addition, it reached over $150 \%$ of its original activity after incubation in $\mathrm{pH} 10$ for $15 \mathrm{~min}$. (Figure $3 \mathrm{a}, \mathrm{b}, \mathrm{c}$ and d). It has been reported that their heavy dependence on the extracellular $\mathrm{pH}$ for cell proliferation and enzyme activity would be an important feature of many microorganisms (Kumar, and Takagi, 1999).This is very relevant for their potential use in detergent compositions (Kalisz, 1988), since the $\mathrm{pH}$ of the cleaning detergents is usually 9.0-12.0. This is also very significant. Such results match many recent reports of $\mathrm{pH}$ optimum of 10.0-10.5 (Banik, and Prakash, 2004).

As shown from results, enzyme formulation using Inotech Encapsulator had a high loading capacity where they trap about $92 \%$ of the protease enzyme that is in agreement of that finding of (Bilal, et al., 2017) who analyzed immobilization by enclosures of horseradish peroxidase (HRP) in chitosan beads directed at the deterioration of clothing dyes. After preincubation, the granules of chitosan showed a maximum immobilization yield of about $92.54 \%$. Inotech Encapsulator is built on the creation of beads of a polymer that are reconstituted via a nozzle and manage automated factors (i.e. cutting or friction forces) to improve the correct washing medium at an orifice or disperse the extruder fluid that the polymer provides when passing through the nozzle. By using Inotech Encapsulator the beads are effectively intensified into spherical shapes / capsules after construction (Stark, and Stockar, 2001; Wyss, and Marison, 2005). It has been used at the industrial scale, allowing the production of enough equal amounts of droplets (later made in spheres / capsules). There are 6 main options to insert an object (s) in a sheath relation linked to its encapsulated form, Conservation / stabilization of the incapsulant in response to unpredictable ecosystem reaction and/or possible positions (Security, Maintenance, and Handling, including protection as observed by Ghenem and Ghaly, 2004; Anjaniet al., 2007; Caruso, et al., 2000). Adopted the leakage capabilities of the encapsulating content, including protection, handling and storage as reported ( $\mathrm{Li}$, et al., 2009).

In consideration of the cost cutting of enzyme processing, the reusability of the immobilized enzyme is remarkably effective. This is an important aspect of understanding the economic vitality (Zhang et al., 2005; Wu, and Ma, 2008; Tao et al., 2006). The study concluded enhanced protease activity, due to immobilization gives higher level of operating stability and efficiency (Fortin, and Vuillemard, 1990; Kukubu, et al., 1981; Ramakrishna, et al., 1992; Anisha, and Prema, 2008).

From our study it was illustrated that immobilization of protease in chitosan is the highest matrix over Agar and Alginate that reaches to $151.8 \%$ relative activity by immersion in Oxi detergent but gives about $133.8 \%$ of its relative activity by immersion with Persil detergent which in line with (Kumar, and Bhalla, 2004). 
Surprisingly; blood stains have been more effectively removed than eggs while blood penetrates more readily into the tissues. Nevertheless, our negotiated result could be clarified by the higher protein content of blood (Vasconcelos et al., 2006).

The researchers indicate that in the coming day's revenue research required in order to achieve the maximum efficiency in biotechnological encapsulation technique for pharmaceutical applications. The encapsulation strategy has clearly demonstrated efficient and creative in managing and guiding vast unbelievable outcomes and concepts.

\section{Conclusion}

The current research recorded immobilization in three distinct matrices. When the protease enzyme was immobilized into the chitosan matrix, it resulted in optimum enzyme stabilization. The studied properties make the immobilized protease obtained from Bacillus pseudofirmus Mn6 a good candidate for additives in laundry detergents. The product of this study could be used as detergent or detergent additives. It consists mainly of a biocatalyst namely "alkaline protease". The final product was found or prepared in a usable form stable at room temperature for 40 days and working optimally at $60^{\circ} \mathrm{C}$ and under alkaline $\mathrm{pH} 10$. The immobilized enzyme form in chitosan showed improved characteristics concerning temperature (up to $90^{\circ} \mathrm{C}$ ) and $\mathrm{pH}$ (up to 11) stabilities and high compatibility to work with many tested detergents. In future mixed enzymes can be used in one formulation optimized to work as detergent or /detergent additives. This study confirms the use of formulated detergents which comprise immobilized proteases for household washing. Proteolyses enzymes could be an ideal solution for use in formulas of the detergent.

\section{Acknowledgement}

Authors would like to thank Academy of Scientific Research and Technology, Science and Technology Centre (STC), National Strategy for Genetic Engineering and Biotechnology, Phase II: Applications and Products Development for funding the project No. 4 S- 2014.

\section{REFERENCES}

Abdel-Fattah,Y.R.; El-Enshasy, H.A.;Soliman, N.A. and El-Gendi, H. (2009).Bioprocess Development for Production of Alkaline Protease by Bacillus pseudofirmus Mn6 Through Statistical Experimental Designs, Journal of Microbiology and Biotechnology.19(4):378-86.

Al-Shehri, L.M.; Abdul-Rahman, M. and Yasser, S. (2004). Productionand some properties of protease produced by Bacillus licheniformis isolated from TihametAseer, Saudi Arabia. Pakistan Journal of Biological Sciences. 7: 16311635. 
Anisha, G.S. and Prema, P. (2008).Cell immobilization technique for the enhanced production of $\alpha$-galactosidase by griseoloalbus. Bioresour Technol.99: 3325-3330.

Anjani, K.;Kailasapathy, K. and Phillips, M. (2007).Microencapsulation of enzymes for potential application in acceleration of cheese ripening. International Dairy Journal.17:79-86.

Anson, M.L. (1938).Estimation of pepsin, papain and cathepsin with hemoglobin. Journal of General Physiology. 22: 79-89.

Anwar, A.; Qader, S.;Raiz, A.;Iqbal, S. and Azhar, A. (2009).Calcium Alginate: A Support Material for Immobilization of Proteases from Newly Isolated Strain of Bacillus subtilis KIBGEHAS. World Applied Sciences Journal. 7(10): 1281-1286.

Banik, R.M. and Prakash, M., (2004).Laundry detergentcompatibility of the alkaline protease from Bacillus cereus. Microbiological Research.159: 135-140.

BBC Research. Report BIO030 F Enzymes in Industrial Applications: Global Markets. BBC Research; Wellesley, MA, USA: 2011

Bhaskar, N.;Sudeepa, E.S.;Rashmi, H.N. and Selvi, A.T. (2007).Partial purification and characterization of protease of Bacillus proteolyticus CFR3001 isolated from fish processing waste and its antibacterial activities. Bioresource Technology.98:27582764.

Bilal, M.;Iqbal, H.M.N.; Hu, H.; Wang, W. and Zhang, X. (2017).Enhanced biocatalytic performance and dye degradation potential of chitosan-encapsulated horseradish peroxidase in a packed bed reactor system. Science of the Total Environment. 575: 1352.

Bommarius, A.S. and Paye,M. F. (2013).Stabilizing biocatalysts. Chemical Society Reviews. 42(15) 6534.

Boominadhan, U.;Rajakumar, R.;Sivakumar, P.K.V. and Melvin, M.J. (2009).Optimization of protease enzyme production using Bacillus sp. isolated from different wastes. Botanical Research International.2: 83-87.

Caruso, F.;Trau, D.;Mohwald, H. andRenneberg, R. (2000).Enzyme encapsulation in layer-by-layer engineered polymer multilayer capsules. Langmuir, 16:1485-8. 
Elnashar, M.M.M.; Wahba, M.I.; Amin, M.A. and Eldiwany, A.I., (2014).Application of Plackett-Burman screening design to the modeling of grafted alginatecarrageenan beads for the immobilization of penicillin $G$ acylase. Journal of Applied Polymer Science. 131(11), 40295.

Fortin, C. and Vuillemard, J.C. (1990).Culture fluorescence monitoring of immobilized cells. Physiology of Immobilized Cells.34: 45-55.

Ghanem, A. and Ghaly, A. (2004).Immobilization of glucose oxidase in chitosan gel beads. Journal of Applied Polymer Science.91:861-66.

Grebeshova, R.N.;Saldeco-Torres, L.E. and Hidalgo, M.A. (1999).Serine protease of Bacillus subtilis R. Applied Biochemistry and Microbiology.35:131-134.

Johnsen A. and Flink J.M. (1986). Influence of alginate properties and gel reinforcement on fermentation characteristics of immobilized yeast cells. Enzyme and Microbial Technology. 8: 737-748.

Kalisz, H.M., (1988). Microbial proteinases. In: Fietcher, A.(Ed.), Advances in Biochemical Engineering/Biotechnology,vol. 36. Springer, Berlin Heidelberg New York, pp. 1-65.

Kukubu, T.;Karube, I. and Suzuki, S.(1981). Protease production by immobilized mycelia of Streptomyces fradiae. Biotechnology and Bioengineering.23: 29-37.

Kumar, C.G. and Takagi, H. (1999). Microbial alkaline proteases from a bioindustrial viewpoint. Biotechnology Advances. 17: 561-594.

Kumar, D. and Bhalla, T.C. (2004).Bacillus sp. APR-4 protease as a laundry additive. Indian journal of Biotechnology. 3(4): 563-567.

Li, J.; Jiang, Z.; Wu, H.; Long, L.; Jiang, Y. and Zhang, L. (2009).Improving the recycling and storage stability of enzyme by encapsulation in mesoporous $\mathrm{CaCO}_{3}$ alginate composite gel. Composites Science and Technology.69:539-44.

Lopez, A.;Lazaro, N. and Marques, A.M. (1997). Theinterphase technique: a simple method of cellimmobilization in gel-beads. Journal of Microbiological Methods.30:231-234. 
Melo, A.; Silva, F.; dos Santos, J.; Fernandez-Lafuente, R. and Lemos, T. (2017).Dias Filho, F.,Synthesis of Benzyl Acetate Catalyzed by Lipase Immobilized in Nontoxic Chitosan-Polyphosphate Beads. Molecules.22: 2165.

Moreira, K.A.; Albuquerque, B.F.; Teixeira, M.F.S.; Porto, A.L.F., Lima and Filho, J.L. (2002).Application of protease from Nocardiopsis sp. as a laundry detergent additive. World Journal of Microbiology and Biotechnology. 18(4):307-312.

Nagalakshmi, R. and Ramesh, S. (2009). Studies on the production of protease by Bacillus sp. Recent Research in Science and Technology.1, 250-254

Peinado, P.A.; Moreno, J.J.;Villaba, J.M.; Gonzalez-Reyes, J.A.; Ortega, J.M. and Mauricio, J.C. (2006). Anew immobilization method and their applications. Enzyme and Microbial Technology. 40:79-84.

Ram, B.M.;Jagadeesh, C. and Bose, K. (2012).Production of alkaline protease from Bacillus subtilisby different entrapment techniques. Journal of Biochemical Technology. 4(1): 498-501.

Ramakrishna, S.V.;Jamuna, R. and Emery, A.N. (1992). Production of ethanol by immobilized yeast cells. Applied Biochemistry and Biotechnology. 37: 275-282.

Ramnani, P., Kumar, S.S. and Gupta, R. (2005). "Concomitant production and downstream processing of alkaline protease and biosurfactant from $B$. licheniformis RG1: bioformulation as detergent additive', Process Biochemistry, 4, pp. 3352-3359.

Rezakhani; Ahmad, M.R.;Kazem, P.; Maryam, K. and Sareh, E. (2014).Immobilization of protease in biopolymers (mixture of alginate-chitosan) Nakisa. Journal of Paramedical Sciences (JPS) Autumn. 5(4): 4978.

Sanchez S. and Demain A.L. (2011). Enzymes and bioconversions of industrial, pharmaceutical, and biotechnological significance. Organic Process Research \& Development. 15:224-230.

Sangeetha, R.; Geetha, A. and Arulpandi, I. (2010). Concomitant production, partial purification and characterization of a serine protease and a proteolysis-resistant metallolipase from Bacillus pumilus SG2. Journal of Bioscience. 65:61-65.

Shaheen, M.;Aamer, A.S.; Abdul, H. and Fariha, H. (2008).Influenceof culture conditions on production and activity ofprotease from Bacillus subtilis BS1. Pakistan Journal of Botany.40: 2161-2169. 
Sharifi, M.; Karim, A.Y.; Mustafa, Q.;Nanakali, N.; Salihi, A.; Aziz, F.M.; Hong, J.; Khan, R.H.; Saboury, A.A.; Hasan, A.; Abou-Zied, O.K. and Falahati, M.(2019). Strategies of enzyme immobilization on nanomatrix supports and their intracellular delivery, Journal of Biomolecular Structure and Dynamics.37: 1-19.

Stark, D. and Stockar, Urs von (2001). Extractive Bioconversion of 2-Phenylethanol from L-Phenylalanine by Saccharomyces Cerevisiae, Thesis, 2335, Chemical Engineering, Lausanne, E'cole Polytechnique Fe'de'rale de Lausanne (EPFL).

Susumu, I.;Tohru, K.I. and Katsutoshi, A., et al.(1998).Alkaline detergent enzymes from alkaliphiles:enzymatic properties, genetics, and structures. Extremophiles.2:185190.

Tao, R.;Bai, X.F. and Jiang, L. (2006). New energy of sustainable development in future: production of alcohol fermented by Stover. Liquor Making. 33(3):45-48.

Vasconcelos, A.; Carla, J.S.M.; Silva, M.S.; Georg, M.; Guebitz and ArturCavacoPaulo (2006). Detergent formulations for wool domestic washings containing immobilized enzymes. Biotechnological Letter.28:725-731.

Venugopal M. and Saramma, A.V. (2006). Characterization of alkaline protease from Vibrio fluvialis strain VM10 isolated from a mangrove sediment sample and its application as a laundry detergent additive. Process Biochemistry. 41: 1239-1243.

Wu, X.Q. and Ma, C.L.(2008). Research on ethanol production through corn stalk fermentation. Modern Agricultural Science and Technology.13:240-243

Wyss-Péters, A. and Marison, I.W. (2005). Liquid-core capsules as a tool in biotransformations, Thesis, 3227-6 Chemical Engineering, Lausanne,E'colePolytechniqueFe'de'rale de Lausanne (EPFL).

Zhang, Q.; Lu, J. and Hou, L. (2005). Research progress of alcoholic fermentation of corn stover. Feed Industry. 26(9):20-23. 


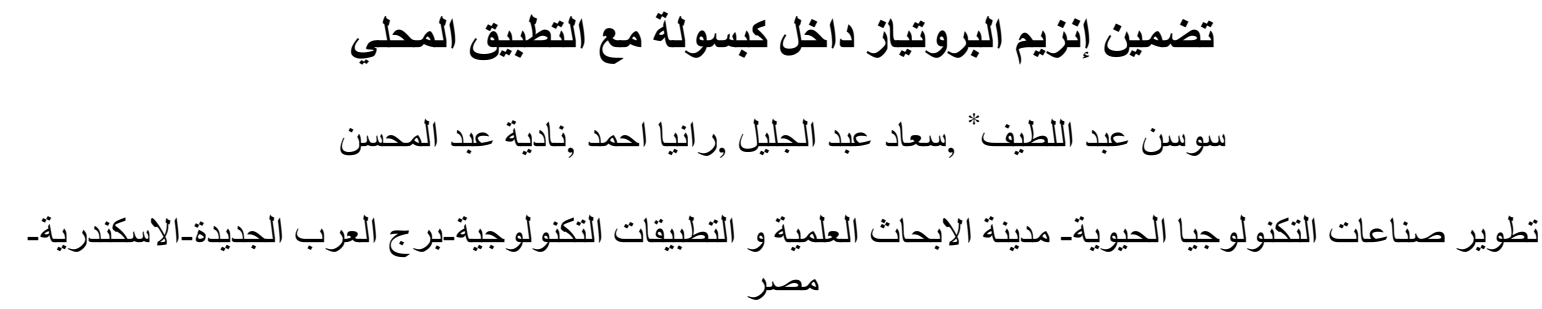

البريد الاكتروني للباحث الرئيسي : sabdellatif@srtacity.sci.egsghany2000@yahoo.com

الملخص :

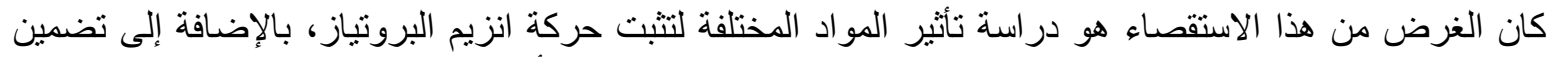

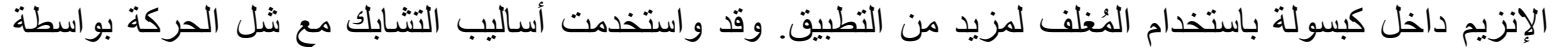

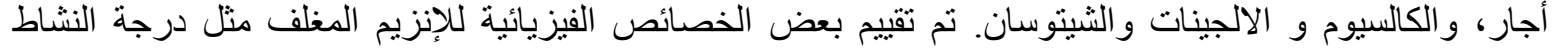

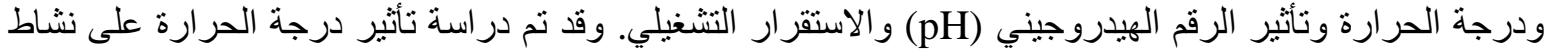

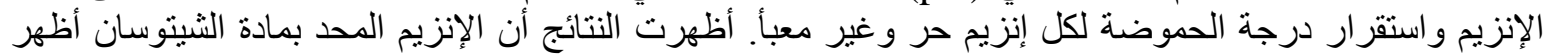

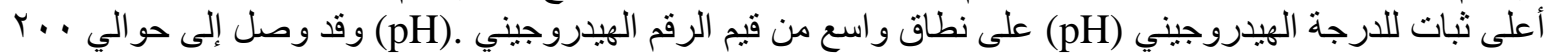

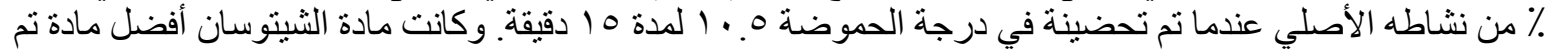

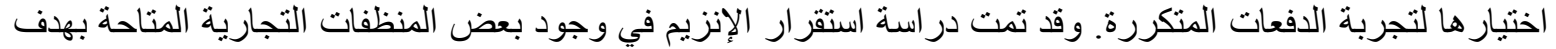

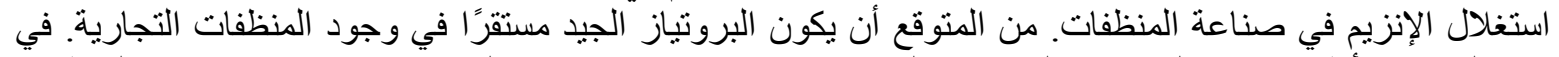

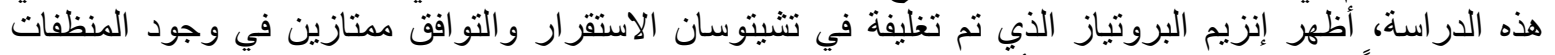

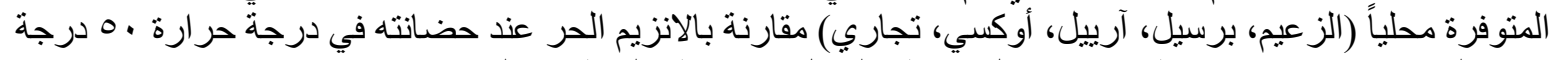

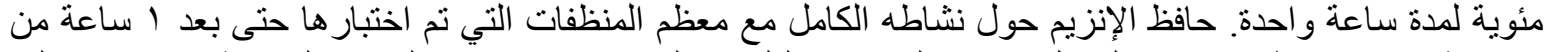

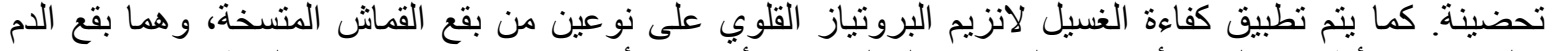

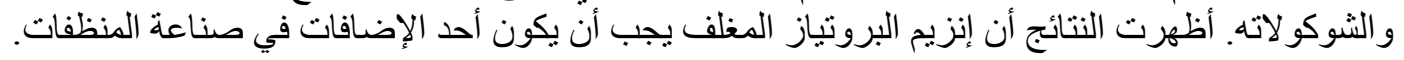

الكلمات المفتاحية: بروتييز، التسكين، مكون الكبسولات، النشاط النسبى، المنظفات 